\title{
Service Delivery: The Perceptions of Users' of Library Services in a Private University in
}

\author{
Peter N. Kiriri \\ United States International University - Africa
}

\begin{abstract}
The success of a library in achieving its target in terms of vision and mission is closely linked to how its users perceive the services offered as well as their attitudes towards the same. The researcher investigates the impact the Library has on students learning through analyzing their perception and attitudes towards the services offered at the library as well as the availability of resources and the relationship of the library users with the library staff. The researcher obtained data from 254 library users, who were issued with a structured questionnaire. The findings of this study showed that postgraduate students used the library more often than their undergraduate counterparts. The study also showed that to a great extent, the library was viewed positively, and this directly affected how the library was used. Based on the findings, this paper recommended that employees undergo customer relation training to improve their relations with users, improve internet speed, and VPN connections, regularly update resources and enforce a noise control mechanism.
\end{abstract}

Keywords: Library services, Library users, Library employees, perception, Library resources, library space.

\section{Introduction}

A library plays a key role in promoting the advancement of knowledge and is integral to the teaching and learning process. That said any parent institution that boasts of a library is mandated to enhance the teaching and learning process through the provision of library services. The International Federation of Library Associations and Institutions (IFLA) has set high standards of provision and delivery of library services, which libraries have to comply with. In order to ensure that the set standards are met, evaluations to assess the strengths and weaknesses in the provision of these services are conducted. It is from the resulting findings that the identified gaps are filled and excellence becomes achievable. User feedback is one of the most effective ways used in the evaluation of library services as this is one of the ways in which a library can remain relevant to the communities they serve [14].

United States International University -Africa boasts of an Ultra-Modern Library and Information Centre that has been in operation since 2007. With an ever-growing student population that now has a total of over 6500 students, it is important that the institution keep abreast of the needs of the students by ensuring the efficiency of its library services in order to achieve its vision of being an institution of academic excellence. The university library has its operations embedded on five core values which are; Life-long learning, Integrity, Innovativeness, Social responsibility, and academic freedom. If these values are to be realized, then how the students perceive the library and the services offered is key to its operations.

The USIU library is not exempt from challenges that students are faced with when using the Library and library services. Though studies have been done on different aspects of services offered in the library, there is still a gap on the general perception the users have of the library and what impact if any this has on their studies and how they view the library. This paper explores the interaction the users have in the library from different perspectives in order to gauge what impact the library staff, resources, environment, and general set-up have on how they view the library. The results from this paper are meant to assist the institution in identifying areas of weakness and strengths. This outcome can then be used to improve on its services with a better understanding of the problem from the user's perspective, as well as measure the steps made towards achieving of the goals of the library. 


\section{LITERATURE REVIEW}

\subsection{Understanding Perception}

The instantaneous response of bodily sensory receptors (eyes, ears, nose, mouth, and fingers) to basic stimuli such as odor, color light, texture, and sound are constituted in the process through which people select, organize and interpret sensations. This entire process is called perception. Perception is the entire process by which an individual becomes aware of the environment and interprets it so that it will fit into their frame of reference. Perception is also defined as the adaptation of reality, whereby inputs from the environment are selected, processed and interpreted to give them a purpose. This alludes that an organism achieves an awareness and understanding of its environment through organizing and interpreting sensory information [36]. Thus, perception is seen as a three-step process of (i) selecting, (ii) organizing, and (iii) interpreting information one is exposed to with a view of using said information in decision making. The information, in this case, is made available through sense organs (i.e., sight, taste, hearing, smell, and touch).

Service providers need to be able to anticipate the needs of a customer as well as demonstrate results to current customers if they are to continue being reliable service providers. Milakovich [21] underscores this point by emphasizing that the manner in which services are provided at the point of customer contact are critical in establishing quality control and sustainable improvement. [21], further states that employees should be aware of the impact their behavior has on a customers' general perception of the establishment. Perception, in this case, is used in reference to how the USIU library users' regard, understand or interpret the library services, resources, and environment as a whole. When the valid customer needs and expectations are met at the point of delivery of a service, then these actions go a long way in shaping the perception and attitude of the customer towards the particular service provider.

\subsection{Service Quality}

In an attempt to define quality various scholars have come up with different definitions such as; conforming to requirement [5], the degree and direction of discrepancy between customers' service perceptions and expectations [26]; customer's judgment of the degree to which their needs and expectations are met [10], Juran [15], sees it as the products ability to meet the requirement that make it fit for use. Wicks and Roethlein [39] claim that there is no acceptable definition of quality, based on the elusive nature of the concept of quality from different perspectives, orientations and the measures applied in a particular context by the person defining it. This implies that quality is subjective and as such what may appear to be qualified for one person may not be true for another. All the definitions of quality given here subject the measure of quality to being the consumer of a product/service, who judges by their own satisfaction. It is therefore principal that in defining service quality one has an understanding of how the consumer of the service feels about the particular service.

In defining 'quality service' used for library evaluation to examine and understand the gap between the library users' expectation and their perception of having these expectations met, service quality is defined by noting the gap reduction in terms of the user expectation versus the actual service provided [13]. Service quality is therefore seen as the difference between the actual customer expectations of service and the perceived service. Thus if expectations outweigh performance, then the perceived quality is deemed to be less than satisfactory thus a dissatisfied customer [27]. Likewise, service is perceived to be of low quality if the expectations happen to be higher than the perception. Service quality is also seen to represent a global judgment about the superiority of service. The exact nature of this attitude is still subject for discussion though it has been suggested that the attitude stems from disconfirmation- a comparison of expectations with performance perceptions [28]; while others argue that it is derived from a comparison of performance with ideal standards [37] or from perceptions of performance alone [37]

Service quality is looked at from various dimensions [12]; 'outcome quality'-is concerned with is concerned with what the service delivers [27]. The second dimension is referred to as the 'technical quality'- this dimension focusses on how the service is delivered and the process the customer goes through to get the particular outcome, also referred to as 'process quality'. While it is evident that a large amount of research has been done in the area of service quality and its measurement, most of what has been published are centered on generic service quality models with little attention being given to context-specific service quality models [7] 


\subsection{Library Services}

In recent years the threat to the very existence of academic libraries has increasingly grown mainly from two fronts: the global digital environment and increased competition caused by the dynamic developments in higher education Academic libraries have a pivotal role in research where they not only pull together discipline-based tools of research but also offer a user-centered customer service [37]. The performance of libraries is increasingly being tied to the quality of services they deliver and it thus follows that libraries have to improve the quality of their services in order to survive [6]. According to Nzivo [23], the service quality in Kenyan libraries was mainly influenced by factors such as user education challenges, an outdated collection of printed material, a lack of electronic resources and a lack of know-how on retrieval on the part of the user. In an earlier study, Burke [3] asserted that Kenyan Public Libraries had not attained world-class status even with the global evolution of libraries.

The Library service quality (LibQual) has been employed as a tool for measuring service quality in libraries and it focusses on three aspects of service quality; the effect of service, information control, and library as a place [19]. The main idea behind LibQUAL is that only the user can judge quality and any other judgment is deemed irrelevant [40]. The Affect of service is measured by focusing on the human dimensions of service quality and bears questions of user interaction with staff [32]. Information control deals with aspects of content including the scope and ease of access; availability of information in a preferred format independently and autonomously [2]. On the other hand, the third dimension of LibQUAL deals with the users' desire for a convenient and conducive physical environment. The questions in this section assess the availability and suitability of the space for individual study, group work as well as research [32].

There has been a radical change in many academic libraries in an attempt to keep up with the ever-increasing pool of online information. Many libraries are now creating spaces to promote document and media production as well as technology, group study spaces, and even coffee shops [1].

\subsection{Library Services and Employees}

Faced with the two major threats alluded to earlier, libraries must not only improve their quality of service but redefine the understanding of quality where quality was traditionally defined in terms of the collection it held and measured by the size of its holding and the various counts of its use. The statistics collected in view of this definition were lacking in relevance according to Peter Hernon and Ellen Altman [29], as they failed to measure the libraries performance against elements that were perceived to be of importance to its users. These statistics did not only fail in assessing the quality of service but also failed to recommend or give guidance as to what could be done to improve service quality [29]. It is essential that the management know and understand the library users' expectations in terms of service delivery and what counts as quality to the user [30]. In their study of service quality and customer satisfaction at Yale University's Libraries, Nitecki \& Hernon [22] arrived at the conclusion that service quality and customer satisfaction can be measured from three dimensions: tangibles. Reliability or service efficiency and affect of service.

In the provision of Library services, the library employees play a major role not only in how the services are provided but also in how they are perceived by Library users. Studies have demonstrated that Library users and how they perceive and use library services are directly connected to how the staff handles the users [25]. Libraries have many opportunities to learn from their users in a way that integrates and communicates value across all areas and create an experience where the user feels appreciated as a valued partner, rather than viewing the library as a transaction point for books, material, and information [33].

Rather than marketing, building relationships have proved to better improve the service industry [33]. Gould stresses the three-point power in empowering the stakeholders as messengers, as they keep an open dialogue, which goes a long way in quality control and improved services. Looking at how Library users perceive the attitude of the Library staff is important because it falls back to the concept that the success or failure of every action in an enterprise is largely dependent on the actions of the front line staff [35].

\subsection{Library Resources}

Libraries have a great responsibility of contributing to and supporting the learning environment. It therefore, follows that thee users will expect that the library services and its material resources are able to meet the users' needs in their ease of access, ease of use and bearing updated content [38]. Library resources are found in various forms within a library such 
as the printed; includes newspapers, books, and magazines which a user can read and be informed, while the non-printed resources include broadcast equipment such as radios, CDs, cassettes etc [9].

In determining the effectiveness of resources available at a Library, the main tool for measurement used would be in having the needs of the Library users satisfied. According to McCarthy [20], in order for an institution to ensure the provision of adequate physical and intellectual access to library resources, it is important that the academic Librarians perform an evaluation of the students' current information needs and satisfaction in using library resources, before they embark on planning and rolling out new services. This view is underscored by Schlichter \& Pemberton [34], where they assert that Planning and evaluation are not independent processes, and that data that is employed in making rational plans for the future is drawn from analyzing the needs of the users' and through measuring how effective the programs and services provided are.

With the ever advancing technology in Libraries and bookkeeping, it is paramount that the users are abreast of these changes and are well equipped to adjust, otherwise their perception and attitude towards the library is affected, as studies have shown. It is this premise that Ocheibi, [24] argues that understanding the actual needs of library users is the surest way of ensuring effective library services.

\subsection{Library Space and Environment}

The needs of the intended users cannot be overlooked when designing a library space because when these needs are met they impact positively on the teaching and learning process in an institution. Despite being in an age where electronic information is readily available, libraries have continued to thrive and their setting and organization has become central to their existence [33]. The International Federation of Library Associations and Institutions (IFLA) recognizes a good library as having these ten qualities; functional, adaptable, accessible, varied, interactive, conducive, environmentally suitable, safe and secure, efficient and suitable for information technology. Though the priority given to each of these qualities is mostly dependent on the mission and culture of a particular institution, these qualities when put together set a library apart from any other building [33].

\section{RESEARCH QUESTIONS}

The study addresses two research questions:

What are the demographic factors affecting the library user's perception in relation to library services?

What is the overall library user perception of students on services provided at the academic library?

\section{RESEARCH METHODOLOGY}

\subsection{Research Design}

For the current study, a cross-sectional descriptive research design was used. A cross-sectional study is defined as an observational research type that analyzes data of variables collected at one given point of time across a sample population. A survey method was used to collect the data on a self-reporting questionnaire. The questionnaire was structured to have collect both qualitative and quantitative data, in which case the qualitative design provided information about the users' experiences, information needs as well as their recommendations [31] while the quantitative design was used in measuring the overall levels of satisfaction and attitudes to different aspects of service delivery [14]

\subsection{Sample and Sampling Procedure}

The sample for this study was drawn from students from a Private University in Nairobi County, Kenya. From a population of about 6,500 students in the Nairobi Campus, using Krejcie and Morgan [17] sample determination formula, a sample size of 361 was used. A purposeful sampling method was used to gather data from both graduate and undergraduate students in the university. The sampling method was used in order to ensure that those who responded were only students who had been in the university for at least 1 year and thus had familiarity with the university library services.

\subsection{Data Collection Methods}

For the purpose of this study, a structured questionnaire with two parts was developed to collect primary data. Part one collected demographic data while part two collected data on perception of library service quality. The questionnaire 
contained only structured questions, using a multiple-item Likert scale with options ranging from "strongly disagree" to "strongly agree." Prior to the data collection, the questionnaire was pre-tested by conducting a pilot study to identify and eliminate possible interpretation problems (to prevent response error) and to assess the reliability of the scale [16]. From the pilot study, there were no changes that were proffered on the questionnaire developed. From the sample size of 361 questionnaires only 254 were returned after filling. Data analysis was carried out using IBM SPSS $®$ version 20.

\section{RESULTS AND FINDINGS}

\subsection{General Information and Demographics}

\subsubsection{Sample Demographic Profile}

As indicated before 361 questionnaires were distributed with $254(70.1 \%)$ returned and usable. From the responses, $40 \%$ of respondents were males while $60 \%$ were females. In terms of the distribution of the respondent's age, $5.5 \%$ were below 20 years; $72 \%$ between $20-30$ years; $21 \%$ between $31-40$ years; and, $2.4 \%$ over 40 years. In terms of the level of study, $63 \%$ were undergraduate, $32 \%$ masters and $5 \%$ doctoral students as indicated in Table 1 below.

Table 1: Sample Demographic Profile

\begin{tabular}{lll}
\hline Gender & Frequency & Percent \\
\hline Male & 102 & 40 \\
Female & 152 & 60 \\
Total & 254 & 100 \\
\hline Age Category & Frequency & Percent \\
\hline Below 20 Years & 14 & 5.5 \\
20 - 30 Years & 182 & 71.7 \\
31 - 40 Years & 52 & 20.5 \\
Over 40 Years & 4 & 2.4 \\
Total & 254 & 100 \\
\hline Occupation & Frequency & Percent \\
\hline Undergraduate & 160 & 63 \\
Graduate (Masters) & 80 & 32 \\
Post Graduate (Doctoral) & 14 & 5 \\
Total & 254 & 100 \\
\hline
\end{tabular}

\subsubsection{Frequency of Library Visits}

The frequency of library visits was analyzed and computed as shown in Table 2. The larger number of respondents agreed to have visited the library once a week (29.9\%) and two to four times a week (21.3\%).

Table 2: Cross Tabulations of Student Status and Frequency of Visits

\begin{tabular}{|l|l|l|l|}
\hline \multirow{2}{*}{ Library visits } & Status of the Student & \multirow{2}{*}{ Total } \\
\cline { 2 - 4 } & Graduate (\%) & Undergraduate (\%) & 2 \\
\hline Never & 2 & 0 & 8 \\
\hline Daily & 4 & 16 & 30 \\
\hline Once a week & 31 & 28 & \\
\hline
\end{tabular}




\begin{tabular}{|l|l|l|l|}
\hline $2-4$ times a week & 20 & 23 & 21 \\
\hline More than 4 times a week & 8 & 7 & 8 \\
\hline Once monthly & 17 & 9 & 14 \\
\hline Twice monthly & 11 & 5 & 9 \\
\hline Once a semester & 2 & 7 & 4 \\
\hline Twice a semester & 5 & 5 & 5 \\
\hline Total & 100 & 100 & 100 \\
\hline
\end{tabular}

\subsubsection{Use of the Library Webpage}

The respondents were asked to indicate how often they accessed the Library services through its Webpage. About $23 \%$ of the respondents had daily access to the library via the web page while $27 \%$ used the web page a couple of times in a week. Another $17 \%$ three to four times a month. A critical $20 \%$ rarely used the webpage whereas $13 \%$ of the respondents had never used the webpage to access the library.

\section{Table 3: Library Webpage Visit}

\begin{tabular}{|l|l|l|l|}
\hline \multirow{2}{*}{ Webpage visit } & \multicolumn{2}{|l|}{ Status of the student } & \multirow{2}{*}{ Total } \\
\cline { 2 - 4 } & Graduate (\%) & Undergraduate (\%) & 23 \\
\hline Daily & 18 & 33 & 27 \\
\hline Often & 32 & 16 & 17 \\
\hline Least often & 17 & 19 & 20 \\
\hline Rarely & 21 & 16 & 13 \\
\hline Never & 12 & 16 & 100 \\
\hline Total & 100 & 100 & \\
\hline
\end{tabular}

\subsubsection{Search Engine Frequently Used}

The respondent were asked to indicate the most frequently used search engine. Google was the most used search engine, with $73 \%$ of the respondents admitting to using for academic research. It was closely followed by Google scholar at $23 \%$, with Yahoo coming a distant third. Some of the respondents were using more than one search gateway, which in most cases were both Google and Google Scholar.

Table: 4 Search Engine Frequently Used

\begin{tabular}{|l|l|}
\hline Search Engine used & Percent \\
\hline Google & 73.2 \\
\hline Google Scholar & 22.8 \\
\hline Yahoo & 2.4 \\
\hline Others & 1.6 \\
\hline Total & 100.0 \\
\hline
\end{tabular}

\subsection{Library Services and Employees}

Findings revealed that the initial point of contact with a library employee was key in the overall experience of the library users. The data analysis showed the importance of being able to cater to the diverse individual needs of each user. For instance, the overall response to the question of whether the library employees gave individual attention differed depending mostly on the age and gender of the respondents. Females demonstrated the need for more individual attention than did the men, as more men than women responded with stronger terms leaning towards agreeing, while the curve for the women's response was mostly neutral as displayed in Figure 1. 


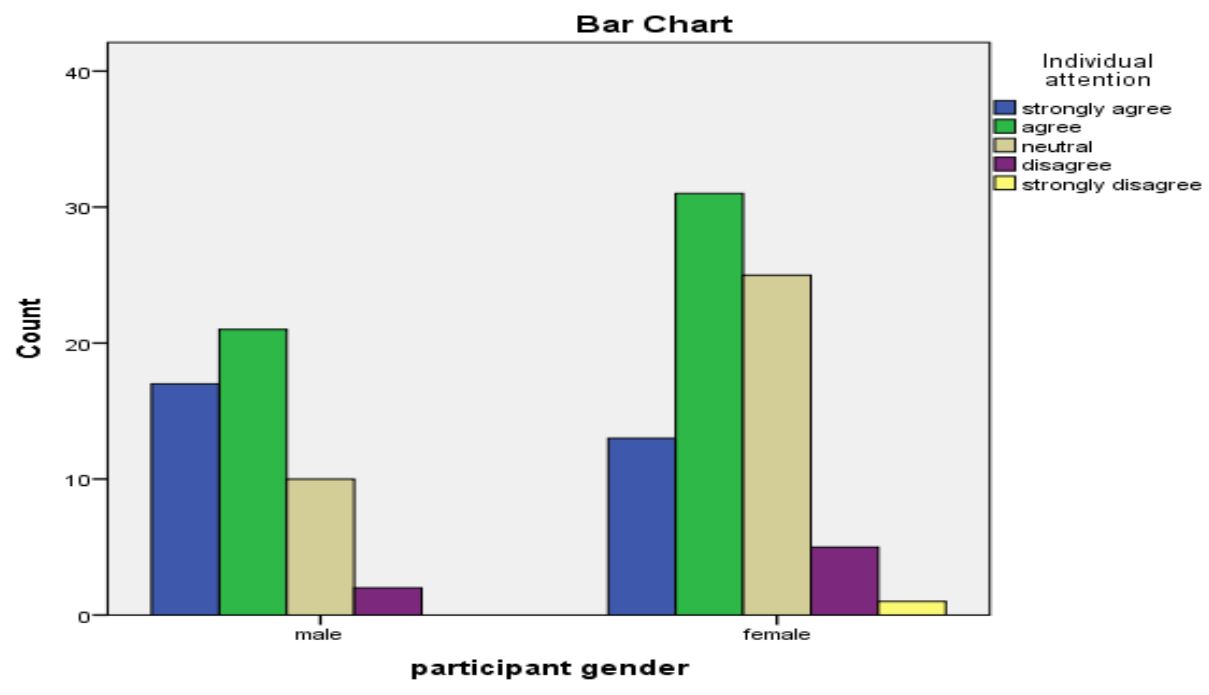

Figure 1: Individual Attention from the Library Employees

At the same time the age of the participant also had an impact on how they interacted with the library employees as is evident in Figure 2 below.

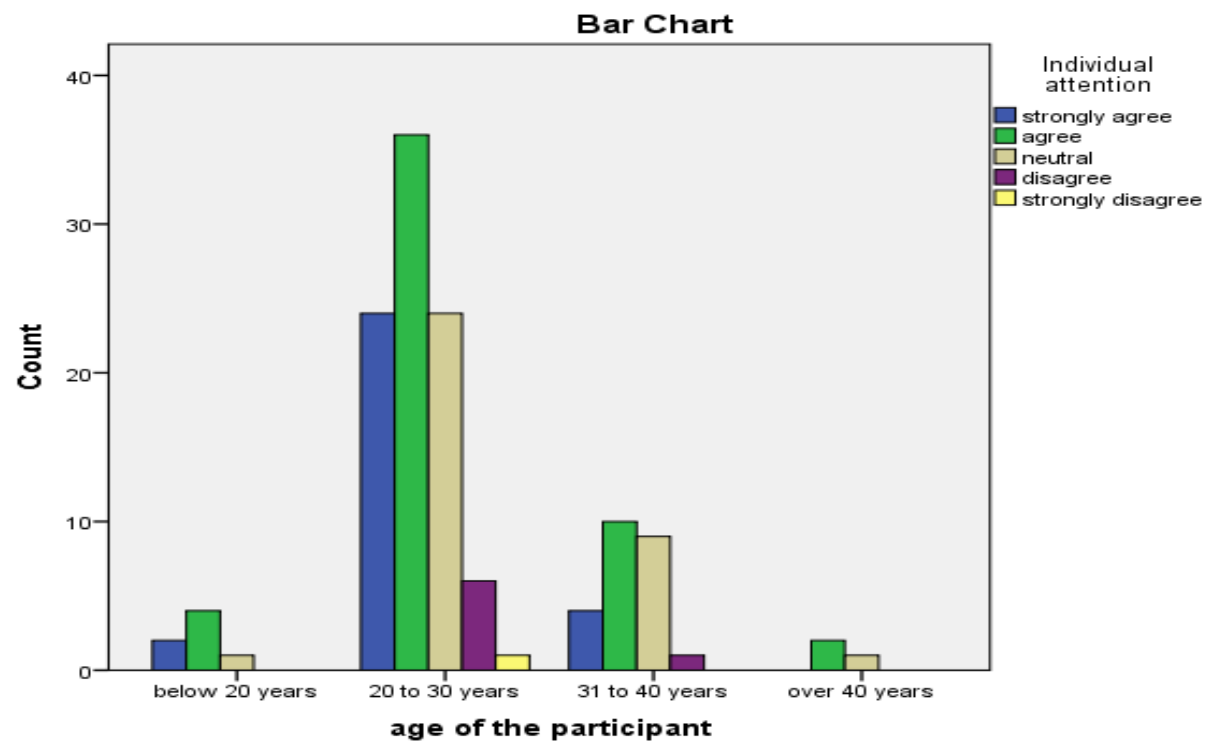

Figure 2: Age and Individual Attention from Library Employees

The study sought to know the students perception based on various employee characteristics. The results show that more than $75 \%$ of the respondents viewed the library employees positively. However, there were issues pertaining to various aspects of the services offered by the employees. These came in the form of suggestions where the respondents felt, the library staff should be able to take initiative in assisting students, increase employee/student interaction, increased 
individual attention and increase in the number of library attendants. These findings indicate that personalized attention from Library employees is very important to the users and how they feel about the library.

Table 5 Students' Perception towards the Library Employees and their Attitudes

\begin{tabular}{|c|c|c|c|}
\hline Employee Variables & Agree & Neutral & Disagree \\
\hline Individual attention & $65.2 \%$ & $28 \%$ & $6.3 \%$ \\
\hline Instill Confidence & $70.9 \%$ & $23.4 \%$ & $3.2 \%$ \\
\hline Courteous & $67.7 \%$ & $22 \%$ & $7.3 \%$ \\
\hline Readily respond to questions & $75.2 \%$ & $18.4 \%$ & $6.4 \%$ \\
\hline Knowledge to answer questions & $70,3 \%$ & $25.8 \%$ & $4 \%$ \\
\hline Caring & $60.8 \%$ & $33.6 \%$ & $5.6 \%$ \\
\hline Understand user's needs & $66.1 \%$ & $26 \%$ & $6.3 \%$ \\
\hline Willing to help & $69.3 \%$ & $25.2 \%$ & $3.9 \%$ \\
\hline Dependable in handling lib service user problems & $66.1 \%$ & $24.4 \%$ & $6.6 \%$ \\
\hline
\end{tabular}

\subsection{Library Resources}

As alluded to earlier, the perception and attitude towards resources available in a library is hinged on having the needs of the users' met. This study found that the needs of the library users' in terms of availability of resources and accessibility and ease of use were met to a great extent. The results of the findings are summarized in Table 7 below. This response was replicated across different schools when they were tested for correlation. Though the overall response was positive towards the availability and accessibility of resources, there were respondents who were dissatisfied with the access of the library electronically from their homes or offices.

Table 6: Access of Library Resources

\begin{tabular}{|l|l|l|l|}
\hline Resources & Agree & Neutral & Disagree \\
\hline I can access library electronic resources from my home or office & $61.3 \%$ & $21.0 \%$ & $16.1 \%$ \\
\hline Library website enables me to locate information on my own & $72 \%$ & $21.6 \%$ & $5.6 \%$ \\
\hline Library has the printed library materials I need for my work & $67.7 \%$ & $26.6 \%$ & $5.6 \%$ \\
\hline Library has electronic information resources I need & 67.2 & $24.8 \%$ & $7.2 \%$ \\
\hline $\begin{array}{l}\text { Library has modern equipment that allows easy access to needed } \\
\text { information }\end{array}$ & $79.8 \%$ & $16.1 \%$ & $4 \%$ \\
\hline Library has easy to access tools that allow me to find things on my own & $65.6 \%$ & $28 \%$ & $6.4 \%$ \\
\hline Library makes information easily accessible for independent use & $78 \%$ & $18.5 \%$ & $3.2 \%$ \\
\hline Library has the print/electronic journal collections I require for my work & $71.2 \%$ & $21.6 \%$ & $7.2 \%$ \\
\hline It's easy to the library materials in the stacks in the library & $60.3 \%$ & $29.0 \%$ & $10.4 \%$ \\
\hline $\begin{array}{l}\text { Library has collections of online full-text articles sufficient to meet my } \\
\text { needs }\end{array}$ & $61.6 \%$ & $28.0 \%$ & $8.8 \%$ \\
\hline I use Library for research. & $75.5 \%$ & $14.8 \%$ & $8.8 \%$ \\
\hline
\end{tabular}




\subsection{Library Space}

In line with IFLA's recommendations for the attributes of a good library, this study sought to find out if the users' considered the USIU library a good library. About $83 \%$ of the respondents believed that the setting of the USIU library had space that inspired study and learning, $79.5 \%$ agreed and strongly agreed that the library had space for individual activities, $91.1 \%$ found the library to be set in a comfortable and inviting location, $85.4 \%$ considered the library an ideal getaway for study, learning or research and $70.5 \%$ were in agreement that the library has a community space for group learning and group study/discussion. These percentages are derived from a cumulative percentage of the frequencies under strongly agree and agree. Some of the reasons for not agreeing with the above included; noise especially from undergraduates in study groups, lack of enough room for individual study as the library would tend to be crowded especially during the exams season and inadequate room for group discussions. These findings clearly draw attention to the fact that, though the library bears the qualities of a good library even though there were issues that still needed to be addressed in order to improve the experience of the users'. The findings are as shown in Table 7.

\section{Table 7: Perspective on the Library Space}

\begin{tabular}{|l|l|l|l|}
\hline Space Variables & Agree & Neutral & Disagree \\
\hline Library has space that inspires study and learning & $83 \%$ & $13.8 \%$ & $2.4 \%$ \\
\hline Library has a quiet space for individual activities & $78.7 \%$ & $11.5 \%$ & $9 \%$ \\
\hline Library is a comfortable and inviting location & $90.3 \%$ & $8.1 \%$ & $0.8 \%$ \\
\hline Library is an ideal getaway for study, learning or research & $84.6 \%$ & $9.8 \%$ & $4.8 \%$ \\
\hline $\begin{array}{l}\text { Library has community space for group learning and group study } \\
\text { discussion }\end{array}$ & $69.7 \%$ & $22.1 \%$ & $7.4 \%$ \\
\hline
\end{tabular}

\section{Conclusions and Recommendations}

\subsection{Conclusions}

An overview of the study reveals that the demand for library services is high, dynamic and of diverse nature and the university has to keep up with the changing dynamics in order to ensure the needs of the library users are met. The library to a great extent bears the qualities of a good library, however, there are areas that need improvement especially in creating the library space. The space does not seem to very well cater to quiet individual studies and at the same time group work, the two seem to interfere with each other. In as much as the library resources are well equipped, some of the material available is outdated and issues of access that factor in some of the dynamics that come with the inclusion of technology such as remote access do not appear to meet the expectations of the users. The quality of service delivered and its ability to meet the user's expectations heavily relies on the service providers.

\subsection{Recommendations}

Library employees need to be better equipped and motivated to address the needs of the library users. Library users should be accorded the respect a client is given in a business organization, where their needs are attended to wholeheartedly and in a timely fashion. The library employees should be trained on public relations and attend forums for Librarians, so as to keep abreast with the technology and latest trends in Library keeping.

The University should consider setting aside classes that purely train students on how to use the Library and get the most out of it. This should fill the gap that is created by the user' lack of knowledge of the available resources, as well as reduce the overdependence on Library employees.

The Library should ensure that their resources are constantly updated to avoid cases whereby the users have to heavily rely on other sources just to get information. To achieve its full purpose, the University should ensure the external electronic access is effective and seamless. The Library should also designate group discussion areas that are separate from the individual study areas. This will help minimize the noise distractions and make the environment conducive to all users. Strict noise control policies should be also implemented. 


\section{References}

[1] Accardi, M. T., Cordova, M., \& Leeder, K. (2010). Reviewing the library learning commons: History, models, and perspectives. College and Undergraduate Libraries, 17(2/3), 210 - 329.

[2] Association of Research Libraries (2012). LibQUAL+® Monthly Update. Available at: https://www.libqual.org/news/1295

[3] Burke, J. (2011). User Perceptions of the Library, InfoViews: Insights about Libraries, Research and learning.

[4] C, R. H., M, L. L., \& R, I. R. (1987). User Studies in University Libraries. Paris: UNESCO.

[5] Crosby, Philip B. Quality Is Free: The Art of Making Quality Certain. New York: McGraw-Hill, 1979

[6] Cullen, R. (2001). "Addressing the digital divide", Online Information Review, Vol. 25 Issue: 5, pp.311-320, https://doi.org/10.1108/14684520110410517

[7] Dagger, T. S., Sweeney, J. C. \& Johnson, L.W. (2007). "A Hierarchical Model of Health Service Quality: Scale Development and Investigation of an Integrated Model," Journal of Service Research, Vol. 10, No. 2, 123-142

[8] Edem, N., Ani, O., \& Ocheibi, J. A. (2009). Students' perceived effectiveness in the use of library resources in Nigerian universities. Educational Research and Review, 4(6), 1-5.

[9] Gama, G., Barbosa, F. \& Vieira, M. (2012) Factors Influencing Nurses' Attitudes toward Death. International Journal of Palliative Nursing, 18, 267-273.

[10] Gitlow, H., Gitlow, S., Oppenheim, A, \& Oppenheim, R. (1989). Tools and Methods for the Improvement of Quality, Richard 0. Irwin, Inc.

[11] Gould, M. R. (2009). Building a Community. In The library PR handbook: High-impact communications. Chicago: American Library Association.

[12] Grönroos, C. (1984). "A Service Quality Model and its Marketing Implications," European Journal of Marketing, Vol. 18, No. 4, 36-44. Lehtinen and Lehtinen, 1982

[13] Hernon, P., \& Altman, E. (1998). Assessing service quality: American Library Association.

[14] Janesick, V. J., \& Lincoln, Y. S. (2000). In Handbook of Qualitative Research. In N. K. Denzin (Ed.), The Choreography of Qualitative Research Design' (pp. 379-399). Thousand Oaks, CA: Sage Publications.

[15] Juran, J.M. (1974). Quality control handbook. New York: McGraw-Hill.

[16] Kothari, C.R. (2004). Research methodology: Methods and techniques. (2nd Ed.). New Delhi: New Age international Itd.

[17] Krejcie, R.V. \& Morgan, D.W. (1970). "Determining sample size for research activities", Educational and Psychological Measurement, Vol. 30 No. 3, pp. 607-610

[18] Kroll S. \& Forsman R. (2010). A Slice of Research Life: Information Support for Research in the United States. OCLC Research

[19] Lehtinen, U. \& Lehtinen, J.R. (1982). A Study of Quality Dimensions. Service Management Institute, 5, 25-32

[20] McCarthy, C. A. (1995). Students' Perceived Effectiveness Using the University Library. College \& Research Libraries, 56(3), 221-234. doi:10.5860/crl_56_03_221

[21] Milakovich, M. E. (2006). From quality control to continuous improvement. In Improving service quality in the global economy: Achieving high performance in public and private sectors. Boca Raton, Fla. [u.a.: Auerbach.

[22] Nitecki , D. A., \& Hernon, P. (2000). Measuring Service Quality at Yale University's Libraries. Journal of Academic Librarianship, 259-273.

[23] Nzivo, C. N. (2012). User perception on library services and information resources in Kenyan Public Libraries. Library Review, $110-127$.

[24] Ocheibi, J. A. (2003). Information needs and information gathering behaviour of medical doctors in Maiduguri Nigeria (pp. 417-427). J. Educ. Media Libr. Sci.

[25] Otieno, P. O., Otike, J., \& Rotich, D. (2015). The Effect of Library Staff Attitude to Work on the Use of Information Services in Public University Libraries in Kenya. Asia Pacific Journal of Education, Arts and Sciences, 2(4), 19. Retrieved from http://oaji.net/articles/2016/1710-1465284458.pdf

[26] Parasuraman, A. \& Zeithaml V. (2006). Understanding and Improving Service Quality: A Literature Review and Research Agenda. In B. Weitz and R. Wensley (Ed.), Handbook of Marketing. London: Sage Publications.

[27] Parasuraman, A., Zeithaml V. \& Berry L. (1985). A conceptual model of service quality and its implications for future research. Journal of Marketing. 49(4). 41-50.

[28] Parasuraman, A., Zeithaml V. \& Berry L. (1988). SERVQUAL: A multiple-item scale for measuring consumer perceptions of service quality. Journal of Retailing. 64, 12-37. 
[29] Hernon, P, \& Altman, E. (1998). Assessing Service Quality: Satisfying the Expectations of Library Customers. Chicago, IL: American Library

[30] Calvert, P. (2000). "Service Quality in Libraries," The New Review of Information and Library Research 6 5-23.

[31] Radford, G. P. (2001). Libraries, Librarians, and the Discourse of Fear. The Library Quarterly, 71(3), 299-329. doi:10.1086/603283

[32] Rehman, S., Kyrillidou, M., \& Hameed, I., (2014). Reliability and Validity of a Modified LibQUAL+@Survey in Pakistan: An Urdu Language Experience. Malaysian Journal of Library \& Information Science 19, No 2

[33] Saur, K. G. (2007). IFLA Library Building Guidelines: Developments \& Reflections. K. Latimer \& H. Nieegard (Eds.).

[34] Schlichter, D. J., \& Pemberton, J. M. (1992). The Emperor's New Clothes? Problems of the User Survey as a Planning Tool in Academic Libraries. College \& Research Libraries, 53(3), 257-265. doi:10.5860/crl_53_03_257

[35] St, C. G. (1994). Customer Service in the Information Environment (1st ed.). Berlin/Boston De Gruyter 1994.

[36] Stávková J., Stejskal L. and Toufarová Z. (2008) Factors influencing consumer behaviour, Agricultural Economics- Czech, 54(6): 276-284.

[37] Teas, R.K. (1993). "Expectations, performance evaluation and consumers perception of quality", Journal of Marketing, Vol. 57, pp. 18-34

[38] Terhile, B.F. and Y.A. Anthanisus, 2013. A comparative study on user satisfaction with the management of in library services in three academic libraries Benue State-Nigeria. J. Stud. Soc. Sci., 6: 23-30.

[39] Wicks, A.M., \& Roethlein, C.J. (2009). A satisfaction-Based definition of quality. Journal of Business \& Economics Studies, Vol.15, No.1, spring 2009, 82 - 97.

[40] Zeithaml, V.A., Parasuraman, A. \& Berry, L.L. (1990). Delivering quality service; Balancing customer perceptions and expectations, The Free Press, New York, NY. 